\title{
THEMATIC PROGRESSION VARIATION OF THE GREAT GATSBY ENGLISH- BAHASA INDONESIA TRANSLATIONAL TEXTS
}

\author{
Emi Nursanti ${ }^{1)}$, Asruddin Barori Tou ${ }^{2)}$ \\ Yogyakarta State University ${ }^{1)}$, Yogyakarta State University ${ }^{2)}$ \\ nursanti_emi45@yahoo.co.uk ${ }^{1)}$, asruddintou@yahoo.com ${ }^{2)}$
}

\begin{abstract}
The data-based research on which this article is based aimed at (1) describing the thematic progression variation of The Great Gatsby texts, (2) describing the contextual factors that motivate the variation in question, and (3) describing the effects of the variation on the texts as translational texts. The study applied a qualitative approach which employed a sematic-translational content analysis of qualitative and quantiative data. The results show that thematic progression variation falls into the low category at average indicated by the mean score of 0.76 . The most prominent variation was represented by the low category of variation. The variations were performed by adding or omitting Themes, splitting one units of thematic structure into more than one unit, downranking, not expressing and creating new clauses. The factors that motivate the variation are the different linguistic properties between English and Bahasa Indonesia and the situational contexts. In terms of effects, the variation caused dangling clauses which cannot be identified from which they are developed.
\end{abstract}

Keywords: thematic progression, thematic structure, Theme, Rheme

\section{VARIASI PROGRESI TEMATIK DALAM TEKS TRANSLASIONAL THE GREAT GATSBY BERBAHASA INGGRIS DAN INDONESIA}

\begin{abstract}
Abstrak
Penelitian berbasis data yang menjadi dasar dari artikel ini bertujuan untuk (1) mendeskripsikan variasi progresi tematik dalam teks translasional The Great Gatsby berbahasa Inggris dan Indonesia, (2) mendeskripsikan faktor-faktor kontekstual yang mendorong terjadinya variasi tersebut, dan (3) mendeskripsikan efek-efek dari variasi tersebut terhadap kedua teks sebagai teks translasional. Penelitian ini merupakan penelitian kualitatif dengan data kuantitatif sebagai pendukung. Penelitian ini adalah analisis konten semantik translasional. Hasil penelitian ini menunjukkan bahwa variasi progresi tematik dilakukan dalam jumlah yang kecil dan sebagian besar dalam kualitas rendah yang diindikasikan melalui nilai reratanya yang mencapai angka 0,76. Variasi paling dominan direpresentasikan oleh variasi kategori rendah. Variasi tersebut diwujudkan dengan menambah atau mengurangi Tema, membagi atau menurunkan peringkat satu unit struktur tematik dan tidak mengekspresikan atau menciptakan klausa-klausa baru. Faktor-faktor yang menyebabkan variasi tersebut adalah beberapa sistem bahasa yang berbeda antara Bahasa Inggris dan Bahasa Indonesia serta perbedaan konteks situasi. Dalam kaitannya dengan efek yang ditimbulkan, variasi tersebut menyebabkan munculnya beberapa klausa yang tidak teridentikasi keterkaitannya dengan klausa lain.
\end{abstract}

Kata kunci: progresi tematik, struktur tematik, Tema, Rema 


\section{INTRODUCTION}

Meaning is the critical aspect of translation in translation studies. This is the one which should be understood and then produced in another style, another language, or even another embodiment. Up to now, many theorists still consider the equivalence between translational texts as the ultimate goal of translation. This view is indeed different from the reality that exists in the world of translation since there are many translational texts in which its degree of equivalence is very low but they are still considered as good texts. Besides, as language is contextually motivated, meaning equivalence is rarely achieved. Jacobson via Munday (2008, p.37) gives the same argument by stating that "there is ordinarily no full equivalence between code-units." This is because each language in this world does not share the same features.

One of the terms which are used to conceptualize language variations is register. It is use-related language variations which is motivated by field, tenor, and mode of the discourse. Noticing those register variables, the translator who acts as a communicator should not instantly transfer the meaning but he/she should adjust it to the situational context, cultural context and the communicative needs of the texts.

There are many kinds of texts related to its genre and register. Of all the forms of text translation, literary translation seems to be the most challenging one. Literary translation becomes the most demanding type of translation as it always deal with language and culture puzzlesolving activities, such as language puns, tone, style and inventiveness of the writer, slang, proverbs, colloquialism, knowledge of languages, culture, etc (Landers. 2001, pp.7-8).

Among the various objects of literary translation, novel is one of them and it also becomes the object of translation studies. It catches the translation scholars' attention because translating fiction is actually much more complicated than the translation of other literary genres. It is very complex because in translating novel, the translator does "not only deal with bilingual, but also bi-cultural and bi-social transference" The complex emotions, association, and ideas in the text which are specific to a particular nation's languages, lifestyle and traditions are also should be put into consideration (Yongfang, 2000, p.4).
There are many translational novels which have been published in Indonesia and which have caught people's special interest. The Great Gatsby is one of them. Despite its widespread popularity, The Great Gatsby texts will be chosen as sources of the data in this study because here Fitzgerald demonstrated his ideas and imagination upon the life of Jay Gatsby in relatively long narrative sentence type which is not typical in Bahasa Indonesia (BI). Therefore, analyzing how the translator deals with the different syntactic styles between English and BI is interesting since different culture and linguistic rules may cause problems in translation which finally may lead to meaning variations.

As there are some shared perspectives between Systemic Functional Linguistics (SFL) and translation studies, such as their centrality of meaning where meaning is seen as a choice which is selected from many available options and also the involvement of context in understanding language, this linguistic theory is fit to describe meaning variations in translational texts.

In SFL view, language is structured to make three kinds of meaning simultaneously, i.e. ideational, interpersonal, and textual. Eggins (2004, pp.11-12) states that ideational meaning deals with how people represent experience in language. The interpersonal one is related to social relationship between or among language users and textual meaning deals with information flow.

Among those three metafunctions, the textual meaning is the optimal lens to scrutinize text as its capability to deal with the three linguistic metafunctions in the clauses (McCabe, 1999, p.32). Besides, the researcher preferred to analyze it by considering novel as the object of this study, which is a fiction, and the nature of fiction which shows chronological events where textual elements play important role by connecting an event with other events.

The textual meaning is realized by the Theme pattern of grammar. Theme is the constituent which functions as the point of departure of the message which situates and relates the clause within its context. Meanwhile, the remainder of the message, the part in which the Theme is developed, is Rheme (Halliday \& Matthiessen, 2004, p.64). The Theme and Rheme in a clause give significant contribution of the discourse flow in the whole text. 
The selection and placement of Theme in each clause is actually not too important compared to the overall choice and ordering of Themes in a paragraph because in a paragraph unit, thematic order plays a role in the organization of the text. Ventola \& Mauranen (via McCabe, 1999, p.169) support this argument by saying that "thematic development is important for the readability and clarity of a text." Danes (in Dejica \& Superceanu, 2004, p.47) introduced the term thematic progression to refer to "the way subsequent discourse re-uses previous Themes or Rhemes according to an overall textual plan." It is related to the way Themes and Rhemes are interrelated to achieve the hierarchic organization of the text.

Considering the importance of choices and orderings of Theme in a paragraph compared to the placement of Theme in a clause and considering also a limited number of translational studies talking about thematic progression variation between English and BI, this study preferred to analyze thematic progression variation in paragraph level rather than thematic variation in clause level.

In detail, the objectives of this study are formulated into three points: (1) to describe the thematic progression variation that are represented in The Great Gatsby English-BI texts and their meanings, (2) to describe the contextual factors that motivate the variation in question, and (3) to describe the effects of the variation on the texts as translational texts.

As this study was basically a translational study viewed from linguistic framework, there are two models of analysis which were adopted here. For the linguistic analysis as regard the analysis of Theme-Rheme in each independent conjoinable clause complex, this study applied Halliday's model He said that Theme in English clause is represented by the element that is put in first position which functions as the point of departure and acts to direct the message receiver's attention to the part the sender wishes to emphasize. This is the element which locates and orients the clause within its context. Then, Rheme is the remainder of the message after the Theme is identified. This is the part of the clause in which the Theme is developed. (Halliday \& Matthiessen, 2004, p.64).

Then, as regard the analysis of thematic progression, the choice and ordering of Theme in a paragraph, this study applied Danes' model. He defines thematic progression as "the way subsequent discourse re-uses previous Themes or Rhemes according to an overall textual plan" (Dejica \& Superceanu, 2004, p.47). Further, he proposed four main patterns of thematic progression. The first is constant progression where an element occurs again and again as a Theme in a short period. The second is linear progression where an element which is introduced in the Rheme at the first clause is emphasized or brought again becomes the Theme in the second clause. The third is split progression in which the Theme in a clause contains a lot of information, where each of them is brought as the Theme in sub-sequent clauses. Then, the last is derived progression where the Themes in a paragraph are derived from one hyper Theme.

For the translational analysis of the data, this study applied Asruddin B. Tou's Translatics framework with Translational Semiotic Communication (TSC) as its model of analysis. TSC is the result of connotative (external/contextual) factors and denotative (internal/textual) factors. The connotative ones consist of religious, ideological, cultural, and situational values. Meanwhile, the denotative factors refer to the linguistic factors, such as semantic, grammar, and phonological system. However, due to some limitations on the researcher, the connotative factor which was discussed in this study was only situational context.

Translatics views translation more as an occurrence than a product and it also challenges the transfer/equivalence and hermeneutic-based theories of translation. While both equivalence and hermeneutic frameworks view translational texts as source text (ST) and target text (TT) so that both of them cannot occur simultaneously, as what is stated by Hatim $(2001$, p.27) that translation is the result of a text-processing activity which is done by transposing a SL text into a TL text in which there exist a translational or equivalence relation between the ST and TT, Translatics regards text as "realizer" and it prefers to see translational texts as $\mathrm{T} 1, \mathrm{~T} 2$, and T3 which can occur simultaneously or nonsimultaneously (Tou, 2008, pp.23-24).

A parameter to measure the degrees of thematic progression variation was also applied. This parameter is based on Matthiessen's partitioned multi-register system with common core. This is one of the three approaches he proposed to analyze register. In this approach, each register is considered as consistent with other registers so that there is a common core between them but they are also mutually inconsistent between the subsystems (Matthiessen in 
Ghadessy, 1993, pp.244-249). This approach was chosen because basically there is common core between English and BI but, still, there are also some inconsistencies within their subsystems. This is done by categorizing the variations (inconsistencies) into degrees.

The degrees of thematic progression variation are identified from the number of clauses representing different thematic progression pattern. Zero variation is represented by a translational paragraph with the same thematic progression pattern. Variation one is represented by a translational paragraph with one different clause representing different thematic progression patterns and so on until variation six which is represented by six different clauses. This categorization was based on the rationale that the more different clauses the translational paragraphs have, the more different text developments they bring.

\section{METHOD}

This was a kind of descriptive research in which its aim was to describe objectively the phenomena under research. The approach used in this study was essentially qualitative with complementary quantitative data to support the qualitative analysis. The supportive quantitative analysis was employed to measure the frequency of thematic progression variation degrees based on the occurrence and based on the extent of occurrence and to measure the mean of the thematic progression variation of the texts. Meanwhile, the qualitative analysis was used to describe the data in words, explain the quantitative results and to interpret the contextual motivating factors and the effects of the variation on the texts. This research was a kind of semantic-translational content analysis.

The data in this research were independent conjoinable clause complexes (independent clause with all its hipotactically related clauses (Fries via McCabe, 1999, p.79)) in two bilingual translational texts, i.e. The Great Gatsby texts in English and BI versions. They were chosen as units of analysis because Theme-Rheme occurs at the clause level and "the main contribution (to the method of development of a text) comes from the thematic structure of independent clauses" (Halliday via McCabe, 1999, p.71).

The primary instrument in this research was the researcher (human instrument) and the secondary instruments was the data sheet. In collecting the data, this study used observing method (metode simak). Observing method was done by examining the language use. The data recording was done by reading the text comprehensively and copying each clause in the text on the data sheet.

As this study employed qualitative analysis with supportive quantitative data, there were two kinds of analysis here, the quantitative and the qualitative. To analyze the data quantitatively, the researcher used tabulation technique with the help of the designed parameter to analyze the thematic progression variations in the texts which then produced tables of relative frequencies. In addition, to measure the tendency of the variations, the mean was also measured. Then, for the qualitative analysis, this study used comparative attribution analysis. The two lists compared are the independent conjoinable clause complexes between the English and BI versions. The contextual factors motivating the thematic progression variation and the effects of the variation on the texts as translational texts are further exploration and interpretation upon the investigated phenomena.

\section{FINDINGS AND DISCUSSION}

\section{Quantitative and Qualitative Descriptions: Variation Features}

The placement of Theme and Rheme in a clause does not only give the readers orientation where the clause's departure point is, but it also suggests the flow of information. The distribution of information in a certain text is not random. In making a series of sentences becomes a meaningful discoursal unit, the writer puts certain information as a topic in each clause in order to be connected with other information in other clauses. The interaction of Theme with other Themes or with Rhemes provides continuity in the discourse and organizes the text.

In respect to the translation of prose which shows chronological interconnected plot, these findings can be used to determine the degree of text's readability and comprehensibility because clauses with interconnected Theme or Rheme are easier to be understood than those with less-related information. In order to identify the main tendency of thematic progression variation in the texts, a quantitative analysis measuring its mean is necessary. This analysis can provide information on how far the translator changed the thematic progression patterns of T1. The quantification is shown in the table below. 
Table 1. The Frequency of Thematic Progression Variations

\begin{tabular}{cccc}
\hline $\begin{array}{c}\text { Range } \\
\text { Category }\end{array}$ & $\begin{array}{c}\text { Range } \\
\text { Subcategory } \\
\left(\boldsymbol{x}_{i}\right)\end{array}$ & $\begin{array}{c}\text { Frequency } \\
\left(\boldsymbol{f}_{i}\right)\end{array}$ & $\boldsymbol{f}_{i}, \boldsymbol{x}_{i}$ \\
\hline \multirow{3}{*}{ Low } & 0 & 169 & 0 \\
& 1 & 119 & 119 \\
Medium & 2 & 40 & 80 \\
& 3 & 10 & 30 \\
High & 4 & 3 & 12 \\
& 5 & 3 & 15 \\
& $\sum$ & 1 & 6 \\
\hline
\end{tabular}

$$
\begin{aligned}
\text { Mean } & =\frac{\sum\left(f_{i} x_{i}\right)}{\sum\left(f_{i}\right)} \\
& =\frac{262}{346}-0.76
\end{aligned}
$$

By the result of 0.76 variations in average, it shows that the translator almost never changed the thematic progression pattern of $\mathrm{T} 1$ in her text or if she did, she did it in a few numbers of clauses. By referring to his result, it can be said that the thematic progression patterns or the patterns of information flow between $\mathrm{T} 1$ and $\mathrm{T} 2$ are not too different. The similar syntactic word order between English and BI is assumed to be the one causing the small average of thematic progression variation.

Besides, in order see the most prominent thematic progression variation that characterizes the texts, a measurement of the occurrence based on the frequency is also necessary. The findings are presented in the table below:

Table 2. The Findings of Thematic Progression Variations Based on the Frequency of Occurrence

\begin{tabular}{cccccc}
\hline Variation & Freq & $\begin{array}{c}\text { Range } \\
\text { Category }\end{array}$ & $\%$ & $\begin{array}{c}\text { Range } \\
\text { Category }\end{array}$ \\
\hline 0 & Lowest & 169 & & $48.70 \%$ & \\
1 & Very & 119 & Low & $34.49 \%$ & Low \\
2 & low & & 328 & $11.59 \%$ & \\
2 & Low & 40 & & $19 \%$ \\
3 & Medium & 10 & Medium & $2.91 \%$ & Medium \\
4 & High & 4 & 14 & $1.16 \%$ & $4.05 \%$ \\
5 & Very & 3 & High & $0.86 \%$ & High \\
& high & & 4 & $0.29 \%$ & $1.16 \%$ \\
6 & Highest & 1 & $\mathbf{3 4 6}$ & $\mathbf{1 0 0 \%}$ & $\mathbf{1 0 0 \%}$ \\
& Total & $\mathbf{3 4 6}$ & &
\end{tabular}

The data findings show that the prominent numbers of variations is successive starting from the low category to the high one. However, the difference of percentage between the most prominent and the second most prominent is so far. In this table, it is shown that the highest number of variation, which is performed by the category of low, is represented by 328 paragraphs among 346 units of analysis. The prominence of the lowest and the low subcategories indicates that most of the paragraphs have the same thematic pattern or if they are different, mostly there is only one clause causing this difference.

In the table, it is shown that $48.70 \%$ of the data are fit in the zero variation. As thematic progression tends to be noticed from the move of topical Themes and because English and BI are subject dominant languages, then the most frequent topical Themes occur must be subject or participant. Then, as subject's placement is not problematic for both languages, topical Theme changing rarely occurs in the $\mathrm{T} 2$ which then causes almost no variation in the thematic progression patterns.

Compared to the low category of variations, the numbers of paragraphs belong to medium category is much less than them. It is possible that this happens because the paragraphs in the data source are mostly short with few numbers of independent conjoinable clause complexes. Thus, the translator has considered that changing two or three thematic progression patterns may change the plot and causing unordered information flow.

Along with the fact that the paragraphs in the data sources, mostly, consist of few numbers of independent conjoinable clause complexes, this is also relevant to the limited numbers of paragraphs identified as belong to the high category because paragraphs containing many clauses are rarely found here. Besides, when the paragraphs of the English version consist of seven or eight clauses, for example, it can be imagined that changing five to six thematic progression pattern, surely, may mess up the plot as well as the information flow. Therefore, the translator chose to keep the thematic progression patterns as in $\mathrm{T} 1$.

Despite considering each frequency of occurrence, in order to see the quality of T2's thematic progression variation, a measurement of value based on the extent of occurrence was also considered. This measurement was done because considering the frequency of each variation based on the occurrence was not enough as it cannot yet accommodate the variation quality done by the translator because each occurrence is regarded as getting one point without 
considering how much varied the clause is. The value used to score the variations in terms of extent of occurrence is same as the degrees of variation. The measurement is presented in the table below.

Table 3. The Findings of Thematic Progression Variations Based on the Extent of Occurrence

\begin{tabular}{|c|c|c|c|c|c|c|}
\hline \multirow{2}{*}{\multicolumn{2}{|c|}{ Variation }} & \multirow{3}{*}{$\begin{array}{c}\text { Freq } \\
169\end{array}$} & \multirow{3}{*}{$\begin{array}{c}\text { Value } \\
0\end{array}$} & \multirow{3}{*}{$\begin{array}{c}\text { Ext } \\
0\end{array}$} & \multicolumn{2}{|c|}{ Range Category } \\
\hline & & & & & \multirow{2}{*}{ Ext } & \multirow[t]{2}{*}{$\%$} \\
\hline 0 & Lowest & & & & & \\
\hline 1 & Very & 110 & 1 & 110 & \multirow{3}{*}{$\begin{array}{c}\text { Low } \\
199\end{array}$} & \multirow{3}{*}{$\begin{array}{c}\text { Low } \\
74.81 \%\end{array}$} \\
\hline 1 & low & 117 & 1 & 117 & & \\
\hline 2 & Low & 40 & 2 & 80 & & \\
\hline 3 & Medium & 10 & 3 & 30 & \multirow{2}{*}{$\begin{array}{c}\text { Med } \\
46\end{array}$} & \multirow{2}{*}{$\begin{array}{c}\text { Med } \\
17.29 \%\end{array}$} \\
\hline 4 & High & 4 & 4 & 16 & & \\
\hline 5 & Very & 3 & 5 & 15 & \multirow{2}{*}{$\begin{array}{c}\text { High } \\
21\end{array}$} & \multirow{2}{*}{$\begin{array}{c}\text { High } \\
7.90 \%\end{array}$} \\
\hline \multirow{2}{*}{6} & Highest & 1 & 6 & 6 & & \\
\hline & Total & 346 & & 266 & 266 & $100 \%$ \\
\hline
\end{tabular}

As can be seen the table above, the findings based on the occurrence and based on the extent are similarly successive in terms of most-prominent variation, from the low, to the medium, then to the high category.

Although the values of the medium and the high category are higher than the values of the low one, still the low category is more dominant. In terms of quality, the low percentage of the medium and high categories indicates that the translator rarely did "high-level" of variations. There are some possible factors motivating them, i.e. (1) the translator did not aware of the importance of thematic progression in developing text or even she did not aware that thematic progression patterns exist in the process of developing text, (2) the translator intentionally avoided high-level variations because she saw herself as the one who should be 'obedient' to T1, therefore too much changing may cause $\mathrm{T} 2$ to be much different from $\mathrm{T} 1$, and (3) the limited number of T1 paragraphs containing more than 5-6 clauses therefore changing all of them may mess up the message conveyed in $\mathrm{T} 1$.

\section{Data Analysis of Each Subcategory}

Low Category

The translational paragraphs which are identified as belong to the low category are of course those which contain insignificant changes. Zero variation or the lowest variation, variation one or the very low variation, and variation two or the low one are the subcategories of the low category.

\section{Variation 0}

Thematic progression variation in zero range is presented by two translational paragraphs which have the same choices of topical Themes and progression patterns. One of the examples can be found in the paragraphs below. They use constant Theme progression pattern. Here the Theme of the first clause is also selected as the Theme of the following clauses.

I hadn't the faintest idea what 'this matter' was, but I was more annoyed than interested. I hadn't asked Jordan to tea in order to discuss Mr. Jay Gatsby. I was sure the request would be something utterly fantastic and for a moment I was sorry I'd ever set foot upon his overpopulated lawn.

Aku tidak memiliki secuilpun pikiran mengenai apakah yang dimaksud dengan 'masalah ini', tapi aku merasa lebih terusik daripada penasaran. Aku tidak pernah mengajak Jordan pergi minum teh untuk membicarakan Tuan Jay Gatsby. Aku yakin jika permintaan yang diajukannya pastilah sesuatu yang luar biasa dan selama beberapa saat aku merasa menyesal pernah menginjakkan kaki di tamannya yang penuh sesak.

As belong to zero variation, those two paragraphs share exactly the same topic. They talk about the ideas that come up in Nick's mind upon Gatsby's statement which says that Gatsby has arranged a meeting between Nick and Miss Baker. From those clauses, evidently Nick Carraway becomes the topic center of those paragraphs. Their thematic progressions can be mapped as below:

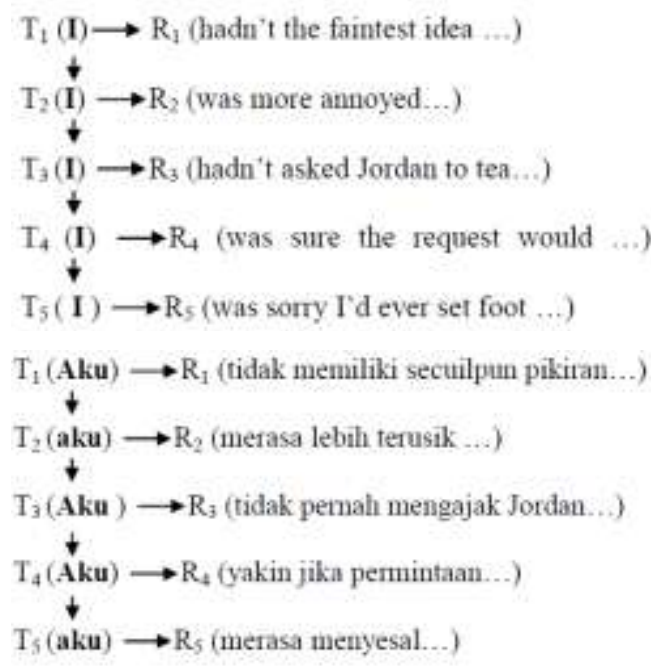

Figure 1. The Example of Thematic Progression Pattern in Variation 0 
By looking at the patterns shown above, it is seen that the successive clauses both in English and BI versions share the same Theme, i.e. $I$. In this case, $I$ refers to the narrator (Nick Carraway). There are no problematic syntactic word orders between BI and English in the clauses above. Therefore, keeping the Themes same as in $\mathrm{T} 1$ is possible.

From the example presented above, it can be concluded that in order to maintain the text development as in $\mathrm{T} 1$, the translator may keep all the thematic elements exactly the same as T1 or he/she can also modify a little by adding or omitting interpersonal and textual Theme. Then, from the readers' perspective, by keeping the thematic progression patterns same as in $\mathrm{T} 1$, the plot remains and the readers of BI version will get the same information in the same way as the readers of English version.

\section{Variation 1}

As designed in the parameter, BI paragraphs which are identified as belong to variation one are those which have one clause representing different thematic patterns. The example of such paragraph is presented below.

(1) Outside the wind was loud (2) and there was a faint flow of thunder along the Sound. (3) All the lights were going on in West Egg now; (4) the electric trains, men-carrying, were plunging home through the rain from New York. (5) It was the hour of a profound human change, (6) and excitement was generating on the air.

(1) Di luar angin bertiup kencang (2) dan terlihat kilatan redup kilat menyambar-nyambar di atas Selat. (3) Cahaya benderang kini terpancar dari sisi West Egg; (4) kereta listrik, mengangkut penumpang, (5) membawa pulang menembus hujan dari New York. (6) Saat ini merupakan jam-jam pergantian hidup manusia yang luar biasa, (7) dan kegembiraan mengalir di udara.

Throughout this passage, Fitzgerald provides an illustration of the nature at West Egg in one night. All the lights, the electric trains, and the excitement illustrate the energy that comes in West Egg after Gatsby meets Daisy. By saying the wind was loud and there was a faint flow of thunder, it suggests a sudden climate change which implies there is a profound change in Gatsby's feeling because after longing to meet Daisy for many years and after all his very hard struggle, finally he gets together with her in this afternoon.

The plot brought by both the English and BI version of those paragraphs conveys the same matter. However, there is one different clause representing different information. It is in the third clause, the electric trains, men-carrying, were plunging home through the rain from New York which is translational with kereta listrik, mengangkut penumpang, membawa pulang menembus hujan dari New York. In the BI version, men-carrying which is an adjective phrase modifying the electric trains was shifted into one thematic structure. Therefore, it adds one information unit in the BI version. The patterns of their thematic progression are mapped below:

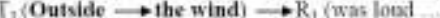

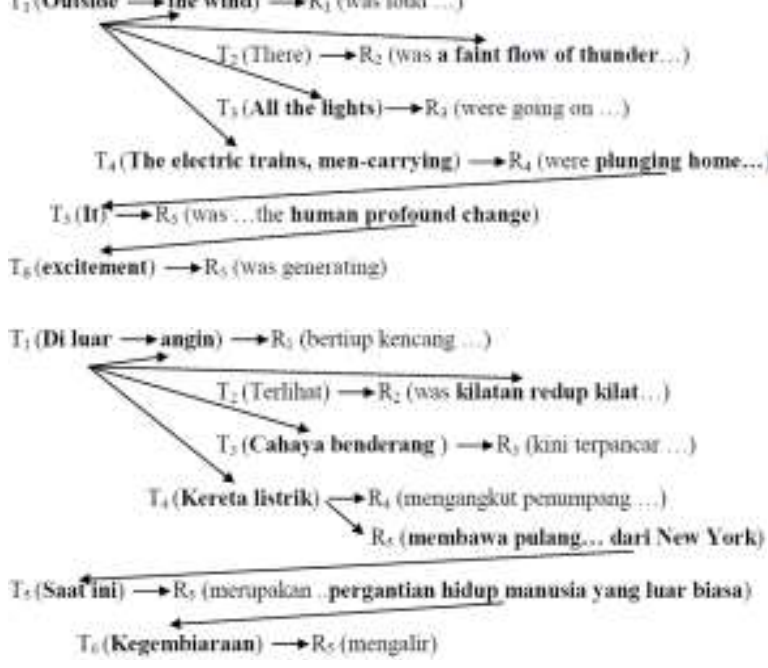

Figure 2. The Example of Thematic Progression Pattern in Variation 1

The paragraph in English version uses mixed progression pattern, i.e. derived-linear progression. The first until the fourth topical Themes are derived from the circumstance outside, which is the circumstance of the first clause. Thus, the first-four successive topical Themes talk about the things found outside Gatsby's house. They are wind, a faint flow of thunder, lights, and electric trains. Then the last two clauses use linear progression pattern in which the topical Theme of the fourth clause, it, is linear with the previous Rheme and the topical Theme of the fifth clause, excitement, is what is actually meant by the Rheme before, i.e. the human profound change.

However, in T2, elliptic progression pattern is added. It is on the fourth clause where one information unit kereta listrik, mengangkut penumpang is provided. As stated before, this information unit occurs because the translator shifted the adjective phrase men-carrying into a clause employing the available participant and it becomes, kereta listrik, mengangkut penumpang (The electric trains were carrying men). It is possible that the shifting is caused by the 
translator misinterpretation upon that adjective phrase. By adding one information unit, the readers get more information. However, it is not effective because in T1, each topical Theme is intended to carry one information unit. By adding one more information unit, the flow of information is not as smooth as in the English version because it seems that the electric trains is more important than other Themes because there are two Rhemes explaining one same Theme.

Based on the analyzed paragraphs, it can be inferred that the T2 paragraphs in variation one still share the same plot as T1. Changing one thematic pattern is not significant to change the information flow.

\section{Variation 2}

When the paragraphs in $\mathrm{T} 1$ and $\mathrm{T} 2$ have two different clauses representing different thematic patterns, then they are identified as included in variation two. By having different thematic patterns because of two different clauses from $\mathrm{T} 1$, it means that the paragraphs are in low variation. The paragraphs below are one of the examples.

(1) The other girl, Daisy, made an attempt to rise - (2) she leaned slightly forward with a conscientious expression - (3) then she laughed, an absurd, charming little laugh, (4) and I laughed too and came forward into the room.

(1) Perempuan lain adalah Daisy, (2) berusaha bangkit, (3) ia agak membungkuk ke depan dengan sikap berhati-hati, (4) kemudian ia tertawa kecil, (5) terdengar absurd namun menarik, (6) dan aku pun ikut tertawa lalu masuk ke dalam ruangan.

Those paragraphs tell about Daisy Baker on what she is doing in a particular room. Here, the first clause of $\mathrm{T} 2$ shifts the participant, the other girl, Daisy, which is in the form of noun phrase, into one independent clause Perempuan lain adalah Daisy (the other girl is Daisy). Therefore, one unit of thematic structure is split into two. Besides, a noun phrase in the third clause, an absurd, charming little laugh, is also shifted into one independent clause with elliptical topical Theme, terdengar absurd namun menarik. The different patterns is presented below.
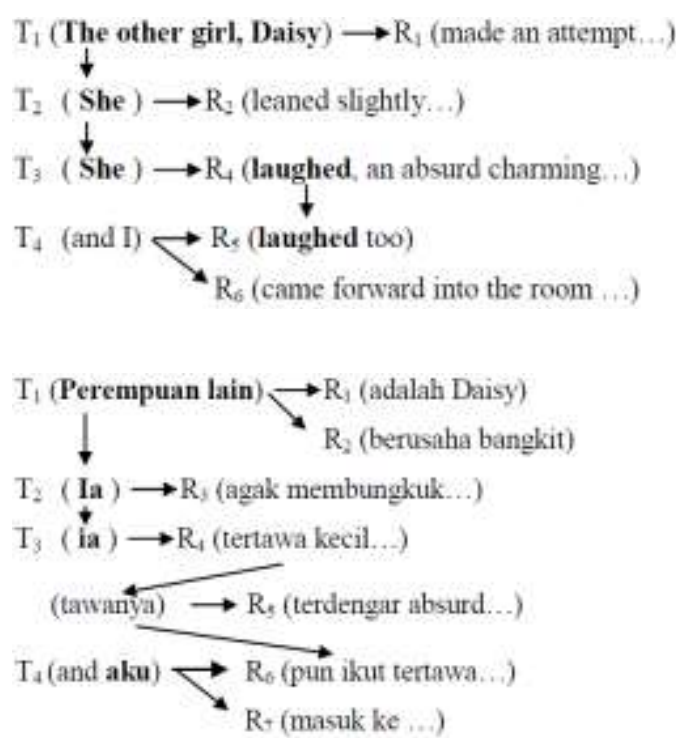

Figure 3. The Example of Thematic Progression Pattern in Variation 2

\section{Medium Category}

The subcategories which belong to the medium category are variation three or the medium variation and variation four or the high one. In accordance to the category they belong to, the paragraphs which are identified as the medium category are those which have already performed thematic progression variation in quite considerable quality.

\section{Variation 3}

Variation three identifies translational paragraphs with three clauses representing different thematic progression patterns. Variation three is categorized as medium variation. Thus, paragraphs which included in this variation have already had significant differences from $\mathrm{T} 1$. One of the data belong to variation three is presented below.

(1) Something in her tone reminded me of the other girl's 'I think he killed a man,' (2) and had the effect of stimulating my curiosity. (3) I would have accepted without question the information that Gatsby sprang from the swamps of Louisiana or from the lower East Side of New York. (4) That was comprehensible. (5) But young men didn't - drift coolly out of nowhere and buy a palace on Long Island Sound. (6) At least in my provincial inexperience $I$ believed they didn't-

(1) Nada suaranya mengingatkanku pada gadis yang berkata, 'kurasa ia pernah membunuh seseorang' (2) dan keduanya memiliki efek yang sama pada kepenasarananku. (3) Aku menerima informasi tanpa bertanya lagi bahwa Gatsby mendadak pindah dari Louisiana atau dari 
bagian bawah sisi timur New York. (4) Berita ini dapat dipahami. (5) Tapi seorang laki-laki muda, aku yakin mereka tidak akan bisa pindah dari sebuah tempat dengan mudahnya dan membeli sebuah istana di Selat Long Island, paling tidak sesuai pengalamanku yang tak seberapa.

At a glance, both paragraphs talk about the same matter. They talk about Nick's vacillation on where Gatsby lives before he arrives at West Egg and buys an enormous and luxurious house there. However, after comparing both of them in detail, the BI version conveys the plot in different ways. It is seen from the second and last two clauses of that paragraph. In the second clause, the BI version adds topical Theme keduanya (both of them) which is different from what is meant in the English version. By eliminating the topical Theme, the participant meant by the writer is the same participant of the previous clause, i.e. something in her tone. However, by placing participant keduanya, this means both something in her tone and the other girl. Therefore, it delivers different plot.

In addition, the last clause is also different from the English version. The last two clauses in English are contracted into one clause in BI becomes Tapi seorang laki-laki muda, aku yakin mereka tidak akan bisa pindah dari sebuah tempat dengan mudahnya dan membeli sebuah istana di Selat Long Island, paling tidak sesuai pengalamanku yang tak seberapa. Here the translator avoided using young men didn't and they didn't because essentially they refer to the same thing and she does not want to repeat the same thing. However, by this contraction, the clause in BI version is more difficult to be understood. It is possible that the concordance of the elements inside the clause is the cause, for example the word mereka which seems not to refer to anything because the person spoken before is seorang laki-laki muda. The different thematic patterns between the English and BI version of the above paragraph is shown below:

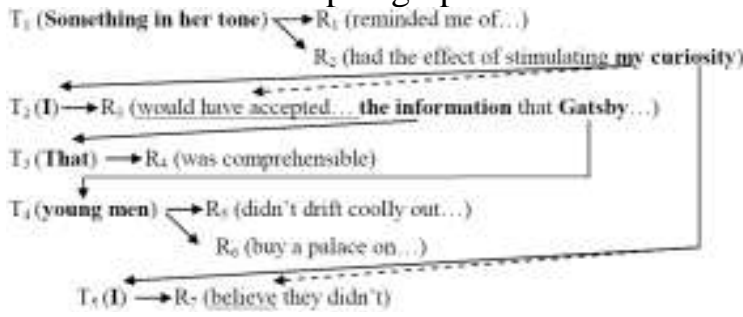

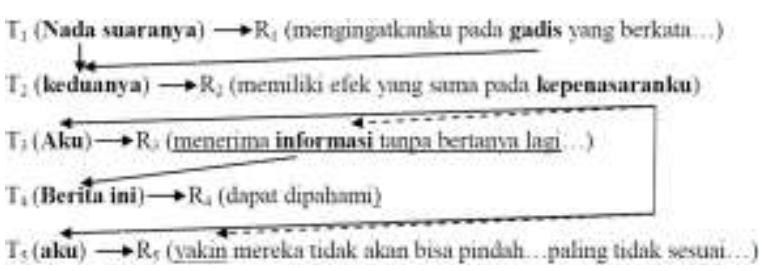

Figure 3. The Example of Thematic Progression Pattern in Variation 3

As shown in the pattern, there are some differences in terms of thematic progression. The second clause of BI version changes the original version which uses elliptic pattern. If in the elliptic pattern the readers can easily infer the participant because it is parallel with the previous clause, using such BI pattern is more complicated because it combines both constant and linear so that the readers have to think what keduanya consists of.

From the example above, evidently, three different clauses may cause significant changes in the thematic progression pattern which significantly affect the information flow of the translated version. Beside affecting the information flow, changing thematic patterns, sometimes, also causes substantial changes in terms of plot.

\section{Variation 4}

Variation four is represented by four different clauses which cause different thematic progression patterns between $\mathrm{T} 1$ and $\mathrm{T} 2$. If variation three has been able to change the information flow significantly, variation four has the greater possibility to change the plot a lot. For a further analysis, the data below are presented.

(1) But above the grey land and the spasms of bleak dust which drift endlessly over it, you perceive, after a moment, the eyes of Doctor T. J. Eckleburg. (2) The eyes of Doctor T. J. Eckleburg are blue and gigantic - (3) their retinas are one yard high. (4) They look out of no face but, instead, from a pair of enormous yellow spectacles which pass over a nonexistent nose. (5) Evidently some wild wag of an oculist set them there to fatten his practice in the borough of Queens, (6) and then sank down himself into eternal blindness (7) or forgot them (8) and moved away. (9) But his eyes, dimmed a little by many paintless days under sun and rain, brood on over the solemn dumping ground.

(1) Setelah menembus tanah kelabu dan hembusan debu yang menghalangi pendangan tanpa berkesudahan, sesaat kemudian kau akan melihat mata Dokter T.J. Eckleburg. (2) Mata raksasa 
Dokter T.J. Eckleburg berwarna biru, dengan tebal retina satu yad. (3) Kedua mata itu tak berwajah, (4) namun memandang dari balik sepasang kacamata besar berlensa kuning yang tergantung di sebuah hidung tak terlihat. (5) Jelas ada seorang dokter gigi memiliki pikiran nakal sengaja menempatkan papan iklan seperti itu untuk menarik pelanggan ke tempat prakteknya di kota kecil Queens, (6) lalu membiarkan matanya menderita kebutaan permanen (7) atau terlupakan begitu saja, (8) dan sang dokter pindah entah ke mana. (9) Namun matanya, yang mulai pudar terpanggang matahari dalam hitungan hari tak berhingga, menatap tajam (10) menyapu seluruh daratan sunyi senyap dan terlantar itu.

Those paragraphs talk about the same thing. It talks about the eyes of Dr. T.J. Eckleburg which become an important symbol in this novel. By becoming the only blue thing in the grey land and the spasms of bleak dust, these eyes may represent something very important. They may represent God's eyes which stare down upon to see the Americans' life. Because of this colorfulness, an oculist also puts yellow spectacles to advertise his service. Although both paragraphs talk about the same thing, the information flow of the BI version is not as smooth as in the English version, especially in the middle until the last part.

The rough text development in $\mathrm{T} 2$ is mostly caused by the occurrences of some Themes or Rhemes which seem unrelated to the previous clausea, such as seorang dokter gigi memiliki pikiran nakal (some wild wag of an dentist) and papan iklan seperti itu (such advertisement) that are unrelated to the textual context provided by the clauses before or that come after. The occurrence of seorang dokter gigi memiliki pikiran nakal is possibly caused by mistranslation where an oculist should be translated as dokter mata and not dokter gigi. Therefore, the words that come after dokter gigi, such as matanya (his eyes), kebutaan (blindness), etc, seem unrelated to the information.

Besides, the word papan iklan seperti itu is also hard to be recognized because what does the word seperti itu refers to is unclear as there is no information before which talks about papan iklan. Here, the translator used papan iklan seperti itu as a translation of the word them which refers to the spectacles. She made such choice because, in BI, the pronoun mereka (them) is not appropriate to refer to inanimate objects. However, because of the Theme jelas ada seorang dokter gigi memiliki pikiran nakal,
BI readers do not get the point that what is meant by papan iklan seperti itu is the spectacles set by the oculist because the oculist does not exist in $\mathrm{T} 2$.

The unrelated lexical choices explained above, surely, make the thematic progression patterns of $\mathrm{T} 2$ are different from its original version. The difference can be seen in the map below:

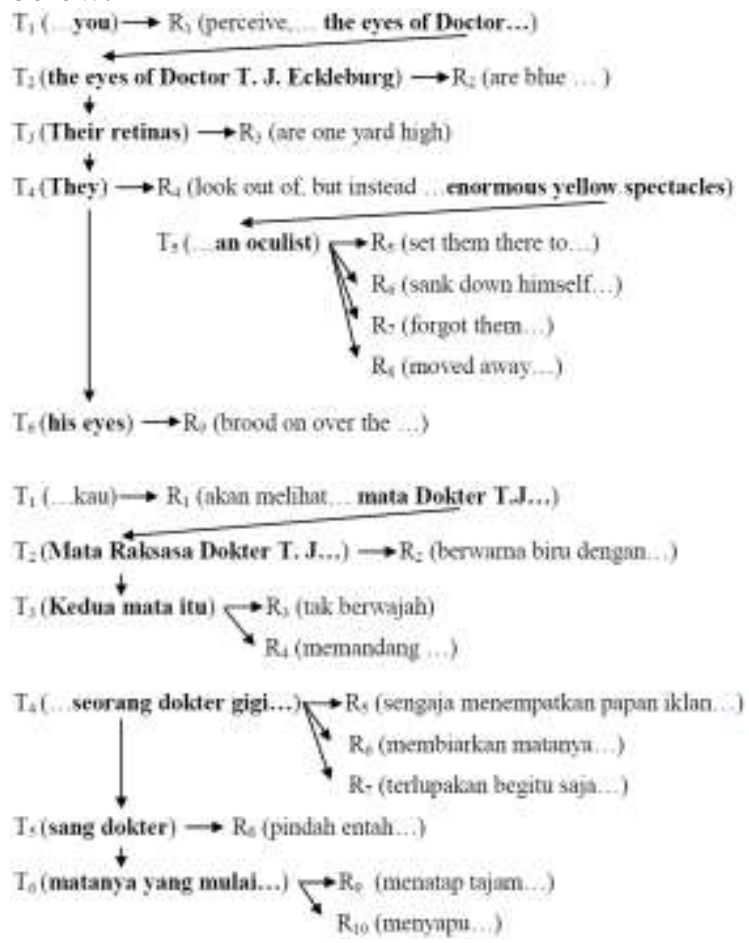

Figure 5. The Example of Thematic Progression Pattern in Variation 4

Although both paragraphs have almost similar patterns, there are still some differences between them. The first is in the third clause with their retinas as the topical Theme which is shifted into adverbial adjunct attached to the clause before. By doing so, the information about their retinas is minor in $\mathrm{T} 2$ and it changes its thematic progression pattern. However, by looking at the next clause, They look out of no face, this changing seems more appropriate because, generally, the ones which look out are the eyes. Retinas do so but it is more specific. Common people are more familiar with eyes than retinas. The third clause of $\mathrm{T} 1$ is also different from the fourth clause of T2. The BI version splits the T1 clause into two. So it creates elliptic progression pattern.

A more significant change is made in the fourth clause of T2. The occurrence of topical Theme seorang dokter gigi does not relate to any Themes or Rhemes mentioned previously. The last topical Theme, matanya, is also 
awkward because in BI the use of -nya means it belongs to the name mentioned before. Thus, it indicates that matanya refers to the eyes of the dentist. In fact, his eyes found in T1 actually refer to the eyes of Dr. T.J. Eckleburg.

Based on that example, a conclusion that can be drawn is that high degree of thematic progression variation indeed brings high degree of text development changing.

\section{High Category}

Within this category, the identified paragraphs are those which show high-level of thematic progression variation by changing five and six clauses in a paragraph. Five different clauses are identified to be variation five or very high subcategory while the six ones belong to the highest subcategory or variation six.

Variation 5

The designed parameter states that variation five is represented by five different clauses between $\mathrm{T} 1$ and $\mathrm{T} 2$ which cause different thematic patterns. The data below are presented to give an example of it.

(1) Already it was deep summer on roadhouse roofs and in front of wayside garages, where new red gas-pumps sat out in pools of light, (2) and when I reached my estate at West Egg I ran the car under its shed (3) and sat for a while on an abandoned grass roller in the yard. (4) The wind had blown off, leaving a loud bright night with wings beating in the trees (5) and a persistent organ sound as the full bellows of the earth blew the frogs full of life. (6) The silhouette of a moving cat wavered across the moonlight (7) and turning my head to watch it I saw that I was not alone-(8) fifty feet away a figure had emerged from the shadow of my neighbor's mansion (9) and was standing with his hands in his pockets regarding the silver pepper of the stars. (10) Something in his leisurely movements and the secure position of his feet upon the lawn suggested that it was $\mathrm{Mr}$. Gatsby himself, come out to determine what share was his of our local heavens.

(1) Suasana puncak musim panas tampak dari pantulan atap rumah-rumah sepanjang jalan dan dari depan garasi, di mana pompa-pompa gas baru berwarna merah tersiram cahaya dan ketika aku tiba di rumahku di West Egg. (2) Kumasukan mobil ke dalam garasi (3) lalu duduk beberapa saat di atas mesin pemotong rumput yang teronggok di halaman. (4) Angin bertiup kencang, menimbulkan kesiur dedaunan yang gaduh di tengah malam yang jernih, (5) ditimpali suara ngorek kodok tanpa henti yang seolah berasal dari bawah tanah. (6) Siluet seekor kucing yang melompat di bawah cahaya bulan membuatku menoleh dan menemukan bahwa diriku tidak sendirian - (8) pada jarak sekitar 20 kaki sosok bayangan seseorang keluar dari rumah tetanggaku (9) dan berdiri dengan menyatukan kedua tangannya (10) memandangi kerlip bintang di langit keperakan. (11) Pada gerakannya yang tenang terdapat sesuatu entah apa (12) dan posisi kakinya yang kukuh menginjak bumi menunjukkan bahwa Tuan Gatsby keluar dengan tujuan untuk menikmati surga di sekeliling kami.

Both of the paragraphs talk about the same thing, i.e. the situation of Nick's surrounding along the ways and after he arrives at home. However, in detail, there are several information units of $\mathrm{T} 1$ which are conveyed in different ways in $\mathrm{T} 2$, for example the second clause, and when I reached my estate at West Egg I ran the car under its shed, which is split into two parts where the circumstantial adjunct is placed in the end of the previous clause. Perhaps the translator did so to emphasize that the deep summer atmosphere is not only found in the way home but also when Gatsby reaches West Egg. However, it changes the meaning core intended by $\mathrm{T} 1$.

Then, another change is that the fifth clause of BI version omits the T1 participant by changing it into passive voice. By this omission, the translator also changes the T1 participant, although it is in ellipsis. Besides, the sixth and seventh clauses of the English version are also different because they are compacted into one thematic structure in BI version. However, the fifth, sixth, and seventh clause of the BI version are still acceptable and easier to understand than the English one although they lessen the importance of some information and the beauty of situational description depicted by Fitzgerald.

The same problem also occurs in the last two clauses, the BI version simplify the clause by splitting it into two thematic structures which means they are easier than the original one. However, by splitting it the translator has add an additional information and the information added is the one which is not intended in the English version. The map below presents the different thematic patterns between the two versions. 


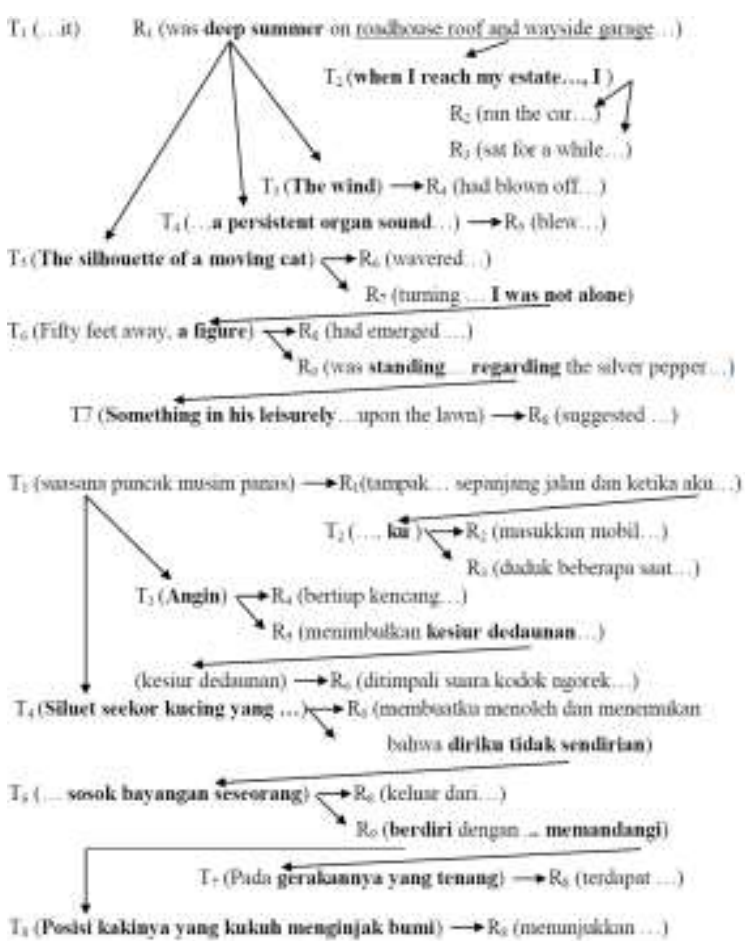

Figure 6. The Example of Thematic Progression Pattern in Variation 5

Based on the patterns shown above, in essence they have the same thematic progression patterns. Basically they use derived progression pattern to describe the situation of deep summer, which is their hyper-Theme. As each topical Theme in the BI version is related with other Themes or Rhemes of the previous clauses, the information flow of this paragraph can be regarded as smooth enough. However, as can be seen in the pattern, the BI version omits one of the hyper-Theme elements, i.e. a persistent organ sound. It is possible that the translator omitted it because essentially it is almost the same as the wind mentioned before. Then, by omitting the topical Theme, the elliptic topical Theme in $\mathrm{T} 2$ is assumed to be kesiur dedaunan (the beating trees) because it is the one which is mentioned in the last time and it is different from T1 topical theme. As a result, what is meant by $\mathrm{T} 1$ is different from what is meant in $\mathrm{T} 2$.

Besides, the differences found in the thematic progression patterns of the paragraphs can also be seen in the last two clauses where one unit of thematic structure in $\mathrm{T} 1$ is split into two in the BI version. By splitting it, the translator has changed the meaning intended by the writer. While the English version wants to say that the ones which suggest that the man Nick sees is Gatsby are something in his leisurely movements and the secure position of his feet upon the lawn, this idea is not expressed in $\mathrm{T} 2$. The BI version changes the plot by saying that there is something in his leisure movement and the secure position of his feet upon the lawn suggested that Gatsby comes out to see his local heavens.

Based on this example, until variation five, it has been proved that higher degree of thematic progression variation suggests higher degree of unordered text development. Then, still, the main problems causing this unordered thematic progression are downranking clause into phrase, splitting one unit of thematic structure into more than one thematic structure, and adding or omitting topical Theme. They may mess up the thematic progression pattern because by doing such things, each clause may lose their 'relatedness' to other clauses.

\section{Variation 6}

Variation six is categorized as the highest variation. It is identified by six different clauses in a paragraph causing different thematic progression patterns. Along with high number of differences, the plot which is intended to be conveyed by the paragraph has greater possibility to change. For further analysis, the data below are presented.

(1) The windows were ajar (2) and gleaming white against the fresh grass outside that seemed to grow a little way into the house. (3) A breeze blew through the room, (4) - blew curtains in at one end and out the other like pale flags, twisting them up toward the frosted wedding cake of the ceiling. (4) The only completely stationary object in the room was an enormous couch on which two young women were buoyed up as though upon an anchored balloon. (5) They were both in white (6) and their dresses were rippling (7) and fluttering as if they had just been blown back in after a short flight around the house. (8) I must have stood for a few moments listening to the whip and snap of the curtains and the groan of a picture on the wall. (9) Then there was a boom as Tom Buchanan shut the rear windows (10) and the caught wind died out about the room (11) and the curtains and the rugs and the two young women ballooned slowly to the floor.

(1) Jendela-jendela itu terbuka sedikit (2) dan berkilat-kilat menghadap tanaman rumput segar di luar yang tampaknya menjorok ke bagian rumah. (3) Desir angin berhembus memasuki ruangan, (4) lalu menggelombang di atas permadani berwarna anggur, (5) menimbulkan bayangan berayun-ayun seperti angin yang berhembus di lautan, (6) membuat gorden di 
salah satu sisi berkibar-kibar lembut seperti bendera yang warnanya memudar, (7) berayunayun di bawah langit-langit dengan cat seperti warna kue perkawinan, (8) Satu-satunya yang benar-benar tidak bergerak di ruangan itu adalah sebuah sofa besar, yang menjadi tempat duduk dua orang muda, (9) mereka tampak mengapung seperti duduk di atas balon. (10) Keduanya memakai gaun putih, (11) dan pakaian mereka kusut masai seolah-olah mereka baru dilanda angin ribut yang menimpa rumah. (12) $A k u$ hanya berdiri terpaku beberapa saat untuk mendengarkan lecutan dan kemerisik gorden menyambar-nyambar dinding dan gemeretak lukisan-lukisan di dinding. (13) Lalu terdengar suara gedebuk keras ketika Tom Buchanan menutup daun jendela (14) dan menyebabkan angin tidak lagi bisa masuk ke ruangan, (15) berhenti mengguncang gorden dan permadani dan dua orang perempuan muda yang duduk mengapung di atas sofa.

By looking at the numbers of clauses the paragraphs consist of, evidently, the BI version has much more clauses than the English one. This is the basic source causing the different thematic progression patterns. Usually, the additional numbers of clauses in the $\mathrm{T} 2$ are mostly caused by split strategy but, in fact, it is not the only one matter. There are more clauses in the BI version because there are two additional clauses which are not translational with T1. In other words, the translator added two clauses based on her own idea. They are placed in the fourth and the fifth clause and they talk about what happen with the breeze after blowing through the room. Although it has been stated that after blowing through the room the breeze blows the curtains and twists them up, the translator added more description about the breeze before blowing the curtains. It is possible that she did so to make the description more real in order to make the readers, as if, feel the described situation.

Although the number of clauses in BI version is greater than the English one, actually, there are two clauses which have been compacted into one. It can be seen in the clause number eleven. The clauses and their dresses were rippling and fluttering as if they... is translated into dan pakaian mereka kusut masai seolah-olah.. The translator did so, perhaps, because the word which is suitable to describe an unsmooth cloth is kusut masai although semantically they are slightly different because rippled and fluttered dress means that the dress moves like small waves because of the breeze while kusut masai means rumpled clothes which is untidy.

The last two clauses are also different because the translator omitted the topical Theme the caught wind and the curtains and the rugs and the two young women and chose to use the shut window as topical Theme but in elliptic form. The shut window is the one which causes the wind died out and stops blowing the curtains and the rugs and the two young women. Then, all the differences explained above cause different thematic progression pattern between $\mathrm{T} 1$ and T2 paragraph. The differences can be seen in the map below:

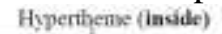

Figure 7. The Example of Thematic Progression Pattern in Variation 6

Based on the map, starting from the second Theme, T2 has changed the English's thematic pattern by adding two more Rhemes from the topical Theme desir angin (a breeze). The additional fourth topical Theme, mereka, is another difference because this is one information structure developed from the previous Rheme. Then, the tenth Rheme is also dissimilar because in $\mathrm{BI}$ there is only one Rheme and there are two in English version. The last dissimilarities is found in the last two clauses which omit the topical Themes the caught wind and the curtains, the rugs, and the young women.

Although there are many differences between the two paragraphs, each Theme or 
Rheme in T2 is related each other. Therefore, the $\mathrm{T} 2$ is quite comprehensible. The content is also still easy to be understood because clauses added are relevant to the previous clause by keeping the same topical Theme. The compacted clause also does not lessen the meaning as the two predicators provided by the English version can be represented by a predicator in BI version. The last two clauses are also not too problematic in terms of information flow because both of them are only Rhemes providing new information about the result of shutting the rear windows which is highly related to the previous clause. Besides, for the last two clauses, the changes are also done for the purpose of creating T2 language which is easy to understand because the caught wind died out.. and the curtains and the rugs and the two young women ballooned... are too awkward to be translated literally.

Overall, it can be summed up that the information flow of $\mathrm{T} 2$ paragraphs has been put into consideration by the translator but still in limited number. Based on the analysis, higher degree of thematic progression variation is not directly proportional to higher degree of unordered or unsmooth information flow. It depends on what kind of changing the translator does and its relation with the Themes or Rhemes mentioned before.

\section{The Low Variation of Thematic Progression}

Referring to the mean of thematic progression variation, reaching 0.76 degree shows that the way the translator developed the text is similar to the original writer. Although there are many additional and omitted textual and interpersonal Themes in a clause but it does not contribute significant changing in thematic progression variation because thematic progression is related to topic movement. Therefore, topical Theme is the core of the thematic progression.

Although in very limited number, higher category of variation also occurs. Their occurrence is caused by some incompatibilities between English and BI where changing some aspects that finally create thematic progression variation is necessary. The translator's strategies causing the variation are splitting one unit of thematic structure into more than one thematic structure, shifting one independent conjoinable clause complex into minor clause, or into phrase, changing the clause's topical Theme, not expressing clause and creating new-existing clause.

\section{Contextual Factors Motivating Thematic Progression Variation}

The variations made by the translator are basically motivated by some factors. The motivating factors may be intratextual, which comes from inside the text, and extratextual, which comes from outside the text.

\section{Different Linguistic Properties between English and BI}

English and BI are languages with SVO pattern. This same syntactic word order is one of the reasons causing low thematic progression variation occur in the texts. Despite of this sameness, still there are some linguistic aspects which are different between the two languages which contribute to the occurrence of the thematic progression variation. The first and most significant difference between them is in terms of complexity.

Compared to BI, English tolerates longer and complicated independent conjoinable clause complexes with many insertions as in I am still a little afraid of missing something if I forget that, as my father snobbishly suggested, and I snobbishly repeat a sense of the fundamental decencies is parcelled out unequally at birth. If that clause is translated literally into BI, the clause will be too difficult to be understood. Therefore, for such clauses, the translator tended to split them into more than one clause in order to make them easier for Indonesian readers.

Another feature of English which are different from BI is the availability of pronoun it. To refer to the thing that has just been mentioned, BI can use some choices, i.e. benda ini, benda itu, or benda tersebut. Thus, talking about the same thing in a paragraph means that the writer has to use those words again and again. As BI does not have such pronoun, in most clauses, the translator then preferred to put the participant into ellipsis. She does so because mentioning the thing again and again will cause a boring text. This phenomenon then caused different thematic progression by creating elliptic progression pattern.

Then, the last feature is related to finite verbal operator functioning as interpersonal Theme in yes/no question. To get an agreement or to check information that has just been heard, English speakers tend to use yes/question, such as Do you?, Can you? or Does she?. However, 
as BI does not have finite verbal operator, especially those which can show time reference, those questions are best translated into Benarkah?. This word has also been able to get an agreement or to check information. However, it is only an exclamation which does not have any thematic structure which is same as Really? in English. Therefore, by translating yes/no question into exclamation, the translator has translated it into minor clause which means she omitted one thematic structure of $\mathrm{T} 1$.

\section{Situational Context}

In terms of situational context, generally the texts have the same situational contexts whether their field, tenor, or mode. For the first context, the field of both texts is same, i.e. the narrators (Nick Carraway and Jordan Baker) tell the life of Gatsby and the people with whom they have relationship with. Therefore, the experiences shared in the texts are mostly Nick's, and a little bit, Jordan's experiences after they know Gatsby. Then, the tenor of the texts is a writer and readers who do not each other doing one-way interaction, the writer gave information all the time and the readers received it so that the clauses employed in the texts are all declarative, except the clauses showing the dialogues between or among the characters. The readers are the one causing different register between the two texts.

Considering the content of The Great Gatsby which tells about love story between Jay Gatsby and Daisy Baker, in which there are adultery and murder, it can be assumed that the target readers of $\mathrm{T} 1$ and $\mathrm{T} 2$ are same, i.e. adolescent or adult readers. As adult readers have had adequate comprehension on language with its grammatical properties, the translator then possibly did not have to modify much the thematic progression pattern of $\mathrm{T} 1$.

However, as one of Fitzgerald's styles in this novel is his long and complex narrative sentences in which Indonesian readers are unfamiliar with that kind of sentence, the translator still needed to modify some clauses in T1 which she felt too complex for Indonesian readers. The modifications were, mostly, done by splitting an independent conjoinable clause complex which is too long and too complex.

In addition, in order to make $\mathrm{T} 2$ becomes so comprehensible and readable that the target readers can easily get the conveyed meaning, the translator, sometimes, also needed to heighten the readability by adding Themes. On the other hand, in some cases where there are repeated Themes in several clauses, the translator also needed to omit some of the Theme for the sake of effectiveness and to avoid a boring text because of the Theme redundancy.

Then, the last, the mode of the texts is written discourse where there are monologues and dialogues there. In the monologue, the most prominent Theme is person Themes talking about the people whom the narrators met, and the other is object Theme, i.e. about the things the narrators see. Then, the dialogues are reflected from the question-answer sequence employing some ellipsis, like yes, no, never, who with?, etc. The interrelatedness among elements in a particular monologue or dialogue is expressed through the use anaphoric references or pronouns which refer to the items mentioned before and through the use of conjunction or conjunctive adjuncts which relate one clause with another one.

\section{The Effects of Thematic Progression Variation on the Texts}

Based on the analysis, the most prominent translational phenomena causing thematic progression variation are topical Theme changing, splitting one thematic structure into more than one thematic structure and shifting or downranking an independent conjoinable clause complex into minor clause, nonfinite clause or word groups forming no thematic structure. The examples of such phenomena are presented in the table below:

Table 4. The Examples of Clauses Causing Different Thematic Progression Patterns

\begin{tabular}{ll}
\hline \multicolumn{1}{c}{ T1 } & \multicolumn{1}{c}{ T2 } \\
\hline at least I had him for a & paling tidak anjing itu \\
few days until he ran & bersamaku beberapa hari \\
away... & sebelum kabur, \\
The apartment was on & (1) Apartemen mereka \\
the top floor - a small & berada di lantai paling \\
living room, a small & atas, (2) terdiri dari \\
dining room, a small & ruang tamu kecil, ruang \\
bedroom and a bath. & makan, kamar tidur dan \\
& kamar mandi, (3) semua \\
& berukuran kecil. \\
at least in my provincial & paling tidak sesuai \\
inexperience I believed & pengalamanku yang tak \\
they didn't- & seberapa, \\
\hline
\end{tabular}

In the first clause, the BI version changes the topical Theme I into anjing itu (the dog). Actually changing the topical Theme is the most significant changing of thematic progression because this Theme is the one which plays great 
contribution toward text development. By changing it of a particular clause, the smooth of information flow in $\mathrm{T} 1$ may be interrupted because all the Themes in the paragraph where that clause belongs to are $I$. However, it does not change the meaning core therefore the plot remains same.

In the second clause, the translator has split one unit of thematic structure into three. Looking from the perspective of a clause as an independent entity, by splitting, the translator has made the text easier to understand. However, from the perspective of thematic progression and information flow, splitting may mean that she also added more information in T2. The matters which are minor in T1, as they are only the topical Themes' supporting details, are placed in an independent thematic structure. Then, if the translator does not put the text development into consideration, she has a great possibility to change the thematic progression of T1 which may also change the plot.

Similarly, the clause consisting of one unit thematic structure which is shifted into a phrase, as the last clause shown in the table, also changes the thematic progression of $\mathrm{T} 1$ and it may also change the plot but it changes it in converse way, i.e. by omitting a unit of information. Because it is in the form of phrase, it does not bring any information. Therefore, it does not play any contribution to the text development.

Based on the explanation above, it seems that the most serious phenomenon causing thematic progression variation is the clauses which contain no information, i.e. the minor clause, downranking clause and the unexpressed clauses. However, as those clauses are rarely found, it can be said that the BI version of the text is almost as readable and as comprehensible as the English version.

To sum up, the effects of thematic progression variation are varied. Sometimes they lessen the text readability and sometimes they strengthen it. Strengthen the meaning clarity is indeed good, but, it is only seen from one perspective, i.e. from the clause as an independent clause which does not relate to other clause. Seen from the perspective of a clause as a part of other clauses which are interrelated each other to create a coherent flow of text, adding thematic elements sometimes create unsmooth information flow. Based on the data in the analysis section, most of the T2 paragraphs which perform different thematic progression patterns from T1, especially those which belong to the medium and high category, have unsmooth text development. However, as the paragraphs which belong to those categories are not many, overall, the readability and information flow of $\mathrm{T} 2$ is very slightly less readable and less comprehensible than $\mathrm{T} 1$.

\section{CONCLUSION}

The mean of the thematic progression variation fit in the category of low category variation. Besides, the low category also dominates the thematic progression variation of the texts. The mean which reach 0.76 degree and the prominence of the low category, both in terms of frequency and in terms of extent shows that the translator kept the information flow of $\mathrm{T} 2$ as similar as possible to T1. Translational phenomena which cause thematic progression variation are omitting or adding topical Theme, splitting or shifting one unit of thematic structure, and not expressing or creating one new thematic structure.

Related to the contextual motivating factors, it is found that the most significant factor motivating the thematic progression variation is the unfamiliarity of Indonesian people to process one long and complicated clause. Other factor which also motivates the variation is the situational context, especially the tenor of the discourse which includes the different target readers of $\mathrm{T} 1$ and $\mathrm{T} 2$.

The variation of thematic progression bring some effects on the text development because by changing the thematic progression patterns, some of the paragraphs in T2, especially those which are included in the high category of variation, had dangling Themes which cannot be traced to which they are related which finally create unsmooth information flow. This finding indicates that the translator, in translating The Great Gatsby, have considered the communicative needs of $\mathrm{T} 2$ but only in the level of clause. She has not yet considered the thematization in the level of paragraph which actually plays more important role in the text development.

\section{REFERENCES}

Eggins, S. (2004). An introduction to Systemic Functional Linguistics (2 ${ }^{\text {nd }} E d$.). New York/London: Continuum.

Dejica, D. \& Superceanu, R. (2004). Thematicstructure analysis of the section 
Statement of Problem in Proposals. Retrieved from http://www.academia.edu/2027067/The matic-

Structure_Analysis_of_the_Section_Stat ement_of_Problem_in_Proposals on January 29, 2013.

Fitzgerald, F. S. (1988). The Great Gatsby. New York: Charles Scribner's Sons.

Halliday, M. A. K. \& Matthiessen, M.I.M. (2004). An Introduction to functional grammar $\left(3^{r d} E d\right.$.). London: Arnold.

Hatim, B. (2001). Teaching and researching translation. Harlow: Pearson.

Landers, C. E. (2001). Literary translation: a practical guide. Clevedon: Multilingual Matters, Ltd.

Matthiessen, C. (1993). Register in the round: Diversity in a unified theory of register analysis. In M. Ghadessy, Register analysis: Theory and practice ( $\mathrm{pp} 221$ 292). London and New York: Pinter Publishers.
McCabe, A. M. (1999). Theme and thematic patterns in Spanish and English history texts (Vol. 1). $\mathrm{PhD}$ thesis, Aston University. Retrieved from http://www.isfla.org/Systemics/Print/Th eses/McCabephd.pdf on January 26, 2013.

Munday, J. (2008). Introducing translation studies: Theories and applications $\left(2^{\text {nd }}\right.$ $E d$.). New York: Routledge.

Nataresmi, U. (2010). The Great Gatsby. Surabaya: Selasar.

Tou, Asruddin B.. (2008). The translatics of translation. Journal of Modern Languages, 18, 15-40.

Yongfang Hu. (2000). The sociosemiotic approach and translation of fiction in Translation journal vol. 4, No. 4 October 2000. Retrieved from http://translationjournal.net/journal/14fi ction.htm on August 13, 2012. 